\title{
Proceeding
}

Supplementary Issue: Winter Conferences of Sports Science. Costa Blanca Sports Science Events, 24 April 2020. Alicante, Spain.

\section{Application of T-Thesys Therapy in post-operative recovery in knee-surgical interventions: A case study}

\author{
VINCENZO CRISTIAN FRANCAVILLA¹, OMAR MINGRINO¹, VALERIO GIUSTINO² \\ IOVANE², GIUSEPPE MESSINA² \\ ${ }^{1}$ Faculty of Human and Society Sciences, University of Enna "Kore", Enna, Italy \\ 2Department of Psychology, Educational Science and Human Movement, University of Palermo, Palermo, \\ Italy
}

\begin{abstract}
T-Thesys therapy is an innovative treatment that can be used even in the presence of recent injuries. For this reason, we studied the T-Thesys use in the post-operative phase of the anterior cruciate ligament (ACL) reconstruction of the knee. For our study, we selected 51 patients for ACL surgery, and we divided participants in two groups: the Experimental Group (EG) and the Control Group (CG). The EG consisted of 34 patients (age: $26.9 \pm 7.65$ years) who underwent T-Thesys therapy after surgery, while the CG included 17 patients (age: $26.7 \pm 6.8$ years) who was not subjected to T-Thesys therapy after surgery. T-Thesys therapy was performed on a daily basis and participants' parameters were monitored throughout the treatment. For the EG, we did not find any significant differences, however, subjective disorders seemed to disappear, almost entirely, at the seventh application. The CG showed no significant differences, even in the subjective disorders investigated. Therefore, the therapeutic treatment associated with T-Thesys therapy seems to not show any efficacy compared to the surgical treatment alone. However, from our findings emerged differences which tend to highlight a better clinical response, a faster recovery time, an improvement on the quality of life in patients, and, moreover, a better use of the National Health System resources.

Keywords: Anterior cruciate ligament; Knee; Rehabilitation; Integrated treatment; T-Thesys therapy.

Cite this article as:

Francavilla, V.C., Mingrino, O., Giustino, V., lovane, A., \& Messina, G. (2020). Application of T-Thesys Therapy in post-operative recovery in knee-surgical interventions: A case study. Journal of Human Sport and Exercise, 15(2proc), S299-S307. doi:https://doi.org/10.14198/jhse.2020.15.Proc2.21

Corresponding author. Department of Psychology, Educational Science and Human Movement, University of Palermo, Palermo, Italy. https://orcid.org/0000-0002-4575-8021

E-mail: vincenzo.francavilla@unikore.it

Supplementary Issue: Winter Conferences of Sports Science. Costa Blanca Sports Science Events, 24 April 2020. Alicante, Spain.

JOURNAL OF HUMAN SPORT \& EXERCISE ISSN 1988-5202

(c) Faculty of Education. University of Alicante

doi:10.14198/jhse.2020.15.Proc2.21
\end{abstract}




\section{INTRODUCTION}

The widespread of mass sport activities and the excessive training in elite sport have increased the phenomena of functional overload syndrome (Franklyn-Miller et al., 2014). The latter often requires immediate diagnostic activities and subsequent applications of non-invasive therapies that allow athletes to return to sport as soon as possible (Badtieva et al., 2018; Dobrindt et al., 2012). For this reason, researchers are always studying novel experimental non-invasive therapies for rapid physical conditioning (Coscia et al., 2019).

The progress of technology, electronics and computer technology applied to medicine has led to an increase in the development and production of electromedical instruments and their consequent use is fundamental in several medical fields (Byrne et al., 2018; Kasha and Banga, 2008; Pariser and Ballard, 2014; Vahed et al., 2018). The electromedical progress has made possible the use of new therapeutic strategies for the treatment of periskeletal soft tissues such as meniscus, ligaments, synovium, cartilages, joints, tendons and muscles with new therapeutic approaches (Foti et al., 2009; Francavilla et al., 2015; Gharaibeh et al., 2012; lovane et al., 2020; Slavotinek, 2010). It is widely known that these structures are easily subject to functional overload injuries and are also difficult to access for treatment (Arnason et al., 2004). The accurate efficiency of these modern electromedical equipment has completed and partly changed the therapeutic procedures, however leaving the main role to surgery.

It is widely recognized that serious and disabling injuries occur by recurrence of previous injuries not completely healed (Aicale et al., 2018). In particular, athletes that are constantly exposed to overuse, due to the sport specific gesture, experience interactive microtrauma (Bell et al., 2018). These types of injuries, because of not occur in specific events but for repetition of a specific and often erroneous sports gesture, are usually underestimated both by the athletes and the coaches with consequent chronicization and deterioration of the athletic conditions (Francavilla et al., 2016).

The concept of clinical recovery of musculoskeletal injuries in athlete should be evaluated following a complete recovery of the injured district, of the areas strictly connected to it and, in general, of the whole organism (Aicale et al., 2018; Bell et al., 2018). The "restitutio ad integrum" of the damage is half of the work. After an injury, the practice to follow should be the use of an effective, time rapid and, concurrently, safe therapy (especially non-invasive) and avoiding, when possible, surgery. Moreover, respect recovery times and modes represent $50 \%$ of the therapy in the athlete.

The surgical intervention, associated with T-Thesys therapy (BIO - EJT SRL; Milan, Italy), allows for a targeted and accurate treatment, thus facilitating faster recovery and safer return to sport avoiding the risk of recurrence.

T-Thesys therapy is an innovative treatment that can be administered even in the presence of recent injuries. Since this treatment does not need for skin contact, we investigated the T-Thesys use in the post-operative phase of the Anterior Cruciate Ligament (ACL) reconstruction in order to evaluate any positive effect. In fact, T-Thesys therapy could be able to relieve pain, reduce inflammation, and recover the joint and its function or, in general, the injured structures involved.

The purpose of this study was to investigate the therapeutic efficacy of T-Thesys treatment in the postoperative phase of knee surgery, that is the reconstruction of the $A C L$, on the effect in recovery time and the consequent athlete's return to sport (Ardern et al., 2016; Toonstra and Mattacola, 2013). 


\section{METHODS}

\section{Participants}

A number of 34 patients (26 males and 8 females; age: $26.9 \pm 7.65$ years) for ACL reconstruction which constituted the experimental group (EG) (Table 1), and a number of 17 patients (10 males and 7 females; age: $26.7 \pm 6.8$ years) for the control group (CG) (Table 2) were recruited for the study. Participants of both groups were homogeneous in terms of characteristics of clinical history and associated pathology to $\mathrm{ACL}$ injury.

Table 1. Clinical history of the EG.

\begin{tabular}{cccccc}
\hline \multirow{2}{*}{ Pathology } & \multicolumn{2}{c}{ Gender $(\mathbf{n}, \boldsymbol{\%})$} & \multicolumn{2}{c}{ Age (mean \pm SD) } & TOT \\
\cline { 2 - 6 } & Female & Males & Females & Males & $(\mathrm{n}, \%)$ \\
\hline Subsidence & $6,18 \%$ & $13,38 \%$ & $32.2 \pm 5.78$ & $27.8 \pm 9.19$ & $19,56 \%$ \\
Medial meniscus injury & $5,15 \%$ & $13,38 \%$ & $23.2 \pm 5.72$ & $24.9 \pm 5.16$ & $18,53 \%$ \\
Lateral meniscus injury & $1,3 \%$ & $5,15 \%$ & 33 & $25.6 \pm 4.1$ & $6,18 \%$ \\
Chondropathies & - & $5,15 \%$ & - & $32.4 \pm 12.18$ & $5,15 \%$ \\
Synovitis & - & $1,3 \%$ & - & 29 & $1,3 \%$ \\
Previous interventions & $6,18 \%$ & $14,41 \%$ & - & - & $20,59 \%$ \\
\hline
\end{tabular}

Legend. EG, Experimental Group; n, number; \%, percentage; SD, standard deviation; TOT, total.

Table 2. Clinical history of the CG.

\begin{tabular}{cccccc}
\hline \multirow{2}{*}{ Pathology } & \multicolumn{2}{c}{ Gender $(\mathbf{n}, \%)$} & \multicolumn{2}{c}{ Age (mean $\mathbf{\pm}$ SD) } & TOT \\
\cline { 2 - 6 } & Female & Males & Females & Males & $(\mathbf{n}, \%)$ \\
\hline Subsidence & $6,35 \%$ & $3,18 \%$ & $32.2 \pm 5.8$ & $22 \pm 6.93$ & $9,53 \%$ \\
Medial meniscus injury & $3,18 \%$ & $3,18 \%$ & $26 \pm 2.83$ & $25 \pm 7.81$ & $7,36 \%$ \\
Lateral meniscus injury & $1,6 \%$ & $1,6 \%$ & 33 & 18 & $2,12 \%$ \\
Chondropathies & $1,6 \%$ & - & 22 & - & $1,6 \%$ \\
Synovitis & - & $1,6 \%$ & - & 24 & $1,6 \%$ \\
Previous interventions & $5,29 \%$ & $2,12 \%$ & $31 \pm 7.53$ & $23 \pm 4.24$ & $7,41 \%$ \\
\hline
\end{tabular}

Legend. CG, Control Group; $n$, number; \%, percentage; SD, standard deviation; TOT, total.

\section{Procedure}

All participants were subjected to a pre-test assessment and a post-test assessment, respectively before and after the rehabilitation protocol including: joint conditions (dry, swelling, mellow, hyperthermia); clinical conditions (arthrocentesis, residual hematoma, articularity, drainage, pain, functional limitations, pain during exercise, subjective disorders) (Monticone et al., 2011). Afterward, the EG was subjected to T-Thesys therapy after surgery, while the CG participants were not given any type of treatment after surgical intervention.

T-Thesys therapy was administered to all EG participants with a daily frequency and an intensity of 4-6 $\mu \mathrm{A}$ for 15 minutes from the day following the intervention and for the entire hospitalization period.

Participants of both groups performed the same post-operative rehabilitation protocol (both for aspects related to medical therapies and for rehabilitation procedures).

The rehabilitation procedure was composed by the following steps (Kvist, 2004):

- $\quad 1^{\text {st }}$ day: bed rest and isometric exercises of the quadriceps; 
- $\quad 2^{\text {nd }}$ and $3^{\text {rd }}$ day: isometric exercises of the quadriceps; walking (using two crutches and to partial load) with a blocked brace in extension to $0^{\circ}$;

- $4^{\text {th }}$ day: knee mobilization up to $90^{\circ}$ with the assistance of the therapist; walking with an articulated brace from $0^{\circ}$ to $90^{\circ}$ and partial load;

- $\quad$ from the $5^{\text {th }}$ until the $7^{\text {th }}$ day (discharge day): knee mobilization associated with isometric exercises.

\section{Statistical analysis}

For statistical analysis we calculated means, standard deviations (SD), percentages (\%) and percentage change $(\Delta \%)$ for studying variables distribution. A t-test for independents groups was computed to compare EG and CG data. For percentages comparison we carried out the formula according to which, to be significant, the difference in absolute value at the level of probability of $5 \%$, must be $\geq$ that multiple of $\mathrm{K}(1.96)$ of the mean square deviation of a normal curve multiplied by the $\sqrt{ }$ of $\sum$ of the products of each percentage ( $p$ ) by the complement $q(q=1-p)$, divided by $N$ of the sample of the other percentage compared:

$$
p^{1}-p^{2} \geq 1.96 . \sqrt{ } p^{1} \cdot q^{1}+p^{2} \cdot q^{2} / N^{2} N^{1}
$$

The significant level was set at $p<.05$.

\section{RESULTS}

The EG showed the following joint conditions results (Table 3): as concern swelling, the $6 \%$ of patients showed this condition at the 1st application, while at the end of the therapy we recorded the $21 \%$ of patients; regarding dryness and mellowness no significant changes were found as described for the application in knee replacement operations (Monticone et al., 2012); while hyperthermia was present only for $18 \%$ of patients and occurred only on the first day.

Table 3. Joint condition for EG (after T-Thesys) and CG.

\begin{tabular}{cccccc}
\hline & \multicolumn{4}{c}{ Joint Conditions (n, \%) } \\
\hline & & Dry & Swelling & Mellow & Hyperthermia \\
\hline \multirow{2}{*}{ 1st $^{2}$ application time } & Group EG & $29,85 \%$ & $2,6 \%$ & $3,9 \%$ & $6,18 \%$ \\
& Group CG & $14,82 \%$ & $2,12 \%$ & $1,6 \%$ & $5,29 \%$ \\
\multirow{2}{*}{$3^{\text {rd }}$ application time } & Group EG & $18,53 \%$ & $11,32 \%$ & $5,15 \%$ & - \\
& Group CG & $10,59 \%$ & $6,35 \%$ & $1,6 \%$ & - \\
$5^{\text {th }}$ application time & Group EG & $8,24 \%$ & $14,41 \%$ & $6,18 \%$ & - \\
& Group CG & $8,47 \%$ & $6,35 \%$ & $3,18 \%$ & - \\
$7^{\text {th }}$ application time & Group EG & $22,65 \%$ & $7,21 \%$ & $5,15 \%$ & - \\
& Group CG & $12,71 \%$ & $3,18 \%$ & $2,12 \%$ & - \\
\hline
\end{tabular}

Legend. EG, Experimental Group; CG, Control Group; n, number; \%, percentage.

For the clinical conditions' evaluations (Tables 4-6), drainage was abundant in $53 \%$ of the $E G$ and moderate in the remaining $47 \%$ of patients, though it was necessary only on the first day after the surgery. At the same time, the $15 \%$ participants of the EG showed residual hematomas that were remained constant until the 7 th application with T-Thesys therapy. The results for the articularity (joint angle degree) showed an increase of $6^{\circ}$ (from $91^{\circ}$ at the 5 th to $97^{\circ}$ at the 7 th application) with a simultaneous and progressive reduction of pain from the 1 st to the 7 th application. Subjective disorders disappeared almost entirely at the 7th application. Furthermore, lower pain level during exercise was found. 
Table 4. Clinical conditions for EG (after T-Thesys) and CG.

\begin{tabular}{|c|c|c|c|c|c|}
\hline & & \multicolumn{4}{|c|}{ Clinical Conditions (n, \%) } \\
\hline & & $\begin{array}{l}1^{\text {st }} \text { application } \\
\text { time }\end{array}$ & $\begin{array}{l}3^{\text {rd }} \text { application } \\
\text { time }\end{array}$ & $\begin{array}{c}5^{\text {th }} \text { application } \\
\text { time }\end{array}$ & $\begin{array}{c}7^{\text {th }} \text { application } \\
\text { time }\end{array}$ \\
\hline \multirow{2}{*}{ Arthrocentesis } & Group EG & $14,41 \%$ & $7,21 \%$ & $6,18 \%$ & $6,18 \%$ \\
\hline & Group CG & $7,41 \%$ & $5,29 \%$ & $3,18 \%$ & $2,12 \%$ \\
\hline \multirow{2}{*}{ Residual hematoma } & Group EG & $5,15 \%$ & - & - & - \\
\hline & Group CG & $2,12 \%$ & - & - & - \\
\hline \multirow{2}{*}{$\begin{array}{c}\text { Articularity (joint angle } \\
\text { degree) }\end{array}$} & Group EG & - & - & $91.3 \pm 6.3$ & $97 \pm 7$ \\
\hline & Group CG & - & - & $91.8 \pm 6.2$ & $99.1 \pm 7.3$ \\
\hline \multirow{6}{*}{ Drainage } & $\begin{array}{l}\text { Group EG } \\
\text { (abundant) }\end{array}$ & $18,53 \%$ & - & - & - \\
\hline & $\begin{array}{l}\text { Group CG } \\
\text { (abundant) }\end{array}$ & $9,53 \%$ & - & - & - \\
\hline & $\begin{array}{l}\text { Group EG } \\
\text { (moderate) }\end{array}$ & $16,47 \%$ & - & - & - \\
\hline & $\begin{array}{l}\text { Group CG } \\
\text { (moderate) }\end{array}$ & $8,47 \%$ & - & - & - \\
\hline & $\begin{array}{l}\text { Group EG } \\
\text { (absent) }\end{array}$ & - & - & - & - \\
\hline & $\begin{array}{l}\text { Group CG } \\
\text { (absent) }\end{array}$ & - & - & - & - \\
\hline
\end{tabular}

Legend. EG, Experimental Group; CG, Control Group; n, number; \%, percentage.

Table 5. Clinical conditions before (pre-test) and after (post-test) treatment for EG (T-Thesys) and CG (no TThesys).

\begin{tabular}{|c|c|c|c|c|c|}
\hline & & \multicolumn{4}{|c|}{ Clinical Conditions (mean \pm SD) } \\
\hline & & $\begin{array}{l}\text { st application } \\
\text { time }\end{array}$ & $\begin{array}{l}3^{\text {rd }} \text { application } \\
\text { time }\end{array}$ & $\begin{array}{c}5^{\text {th }} \text { application } \\
\text { time }\end{array}$ & $\begin{array}{c}7^{\text {th }} \text { application } \\
\text { time }\end{array}$ \\
\hline Pain & $\begin{array}{l}\text { Group EG } \\
\text { Group CG }\end{array}$ & $\begin{array}{c}5.26 \pm 1.94 \\
5.1 \pm 2.3\end{array}$ & $\begin{array}{c}3.62 \pm 1.82 \\
3.5 \pm 2.1\end{array}$ & $\begin{array}{c}2.41 \pm 1.35 \\
2.4 \pm 1.5\end{array}$ & $\begin{array}{c}1.62 \pm 0.64 \\
1.5 \pm 0.7\end{array}$ \\
\hline \multirow{8}{*}{$\begin{array}{c}\text { Functional } \\
\text { limitations } \\
\text { (SCALE) }\end{array}$} & Group EG & $1.59 \pm 0.55$ & - & - & - \\
\hline & Group CG & $1.7 \pm 0.5$ & - & - & - \\
\hline & Group EG & - & $1.15 \pm 0.35$ & - & - \\
\hline & Group CG & - & $1.1 \pm 0.3$ & - & - \\
\hline & Group EG & - & - & $1.06 \pm 0.24$ & - \\
\hline & Group CG & - & - & 1 & - \\
\hline & Group EG & - & - & - & $1.03 \pm 0.17$ \\
\hline & Group CG & - & - & - & 1 \\
\hline \multirow{8}{*}{$\begin{array}{l}\text { Pain during } \\
\text { exercise } \\
\text { (SCALE) }\end{array}$} & Group EG & $2.24 \pm 0.6$ & & - & - \\
\hline & Group CG & $1.4 \pm 0.5$ & - & - & - \\
\hline & Group EG & - & $1.94 \pm 0.59$ & - & - \\
\hline & Group CG & - & $2.1 \pm 0.4$ & - & - \\
\hline & Group EG & - & - & $1.62 \pm 0.49$ & - \\
\hline & Group CG & - & - & $1.6 \pm 0.50$ & - \\
\hline & Group EG & - & - & - & $1.32 \pm 0.47$ \\
\hline & Group CG & - & - & - & $1.2 \pm 0.4$ \\
\hline
\end{tabular}

Legend. EG, Experimental Group; CG, Control Group; SD, standard deviation. Note. Algometric scale subjective, absent pain $=1$ point; maximal pain $=10$ points. 
Table 6. Subjective disorders for EG (T-Thesys) and CG (no T-Thesys).

\begin{tabular}{cccccc}
\hline & & \multicolumn{3}{c}{ Clinical Conditions (mean \pm DS) } \\
\hline & Group EG & $\begin{array}{c}\text { 1st application } \\
\text { time }\end{array}$ & $\begin{array}{c}\text { 3rd application } \\
\text { time }\end{array}$ & $\begin{array}{c}5^{\text {th }} \text { application } \\
\text { time }\end{array}$ & $\begin{array}{c}7^{\text {th }} \text { application } \\
\text { time }\end{array}$ \\
\hline & Group CG & $3.3 \pm 0.43$ & - & - & - \\
Subjective & Group EG & - & - & - & - \\
disorders & Group CG & - & $3.62 \pm 0.59$ & - & - \\
(SCALE) & Group EG & - & $3.8 \pm 0.8$ & - & - \\
& Group CG & - & - & $4.15 \pm 0.49$ & - \\
& Group EG & - & - & $4.4 \pm 0.5$ & - \\
& Group CG & - & - & - & $4.21 \pm 0.4$ \\
\end{tabular}

Legend. EG, Experimental Group; CG, Control Group; SD, standard deviation.

Note. Algometric scale subjective, absent disorder $=1$ point; maximal disorder $=5$ points

Comparison results did not show any significant differences for all the responses of the participants (Table 7).

Table 7. Statistical analysis.

\begin{tabular}{|c|c|c|c|c|c|}
\hline Clinical Conditions & & $\begin{array}{c}1^{\text {st }} \text { application } \\
\text { time }\end{array}$ & $\begin{array}{c}3^{\text {rd }} \text { application } \\
\text { time }\end{array}$ & $\begin{array}{c}5^{\text {th }} \text { application } \\
\text { time }\end{array}$ & $\begin{array}{c}7^{\text {th }} \text { application } \\
\text { time }\end{array}$ \\
\hline \multirow{3}{*}{ Dry } & $\Delta \%$ & 2.9 & 5.9 & 5.9 & 5.9 \\
\hline & Val. & 23.9 & 38.4 & 42.9 & 33.1 \\
\hline & $p$ & n.s. & n.s. & n.s. & n.s. \\
\hline \multirow{3}{*}{ Swelling } & $\Delta \%$ & 5.9 & 2.8 & 6 & 3 \\
\hline & Val. & 55.4 & 46.9 & 46.9 & 53.8 \\
\hline & $p$ & n.s. & n.s. & n.s. & n.s. \\
\hline \multirow{3}{*}{ Mellow } & $\Delta \%$ & 2.9 & 8.8 & 0.1 & 2.9 \\
\hline & Val. & 61.6 & 72.4 & 52.8 & 56.4 \\
\hline & $\begin{array}{c}p \\
\Delta \%\end{array}$ & n.s. & $\begin{array}{l}\text { n.s. } \\
88\end{array}$ & n.s. & n.s. \\
\hline \multirow[t]{2}{*}{ Arthrocentesis } & Val. & - & 24.7 & - & 21.1 \\
\hline & $p$ & & n.s. & n.s. & n.s. \\
\hline \multirow{3}{*}{$\begin{array}{l}\text { Articularity (joint angle } \\
\text { degree) }\end{array}$} & DIFF. & & & 0.5 & 2.2 \\
\hline & MED. & - & - & 0.04 & 0.14 \\
\hline & $\mathrm{P}$ & & & n.s. & n.s. \\
\hline \multirow{3}{*}{ Pain } & DIFF. & 0.16 & 0.12 & 0.01 & 0.12 \\
\hline & MED. & 0.119 & 0.11 & 0.36 & 0.89 \\
\hline & $\begin{array}{c}p \\
\text { DIFF. }\end{array}$ & $\begin{array}{l}\text { n.s. } \\
0.11\end{array}$ & $\begin{array}{l}\text { n.s. } \\
0.05\end{array}$ & $\begin{array}{l}\text { n.s. } \\
0.06\end{array}$ & $\begin{array}{l}\text { n.s. } \\
0.03\end{array}$ \\
\hline Functional limitation & MED. & 0.24 & 0.19 & 0.94 & 1.76 \\
\hline \multirow[b]{2}{*}{ Pain during exercise } & $\begin{array}{c}p \\
\text { DIFF. }\end{array}$ & $\begin{array}{l}\text { n.s. } \\
0.16\end{array}$ & $\begin{array}{l}\text { n.s. } \\
0.16\end{array}$ & $\begin{array}{l}\text { n.s. } \\
0.06\end{array}$ & $\begin{array}{l}\text { n.s. } \\
0.03\end{array}$ \\
\hline & MED. & 0.812 & 2.13 & - & - \\
\hline \multirow{3}{*}{ Subjective disorders } & $\stackrel{p}{\text { DIFF. }}$ & $\begin{array}{l}\text { n.s. } \\
0.15\end{array}$ & $\begin{array}{l}\text { n.s. } \\
0.18\end{array}$ & $\begin{array}{l}\text { n.s. } \\
0.25\end{array}$ & $\begin{array}{l}\text { n.s. } \\
0.29\end{array}$ \\
\hline & MED. & - & - & - & - \\
\hline & $p$ & n.s. & n.s. & n.s. & n.s. \\
\hline
\end{tabular}




\section{DISCUSSION}

The aim of the present study was to evaluate any benefits of the T-Thesys therapy use after ACL reconstruction. The findings we found suggest that the T-Thesys treatment associated to the surgical intervention did not show any significant differences compared to the surgical intervention only.

In particular, outcomes found on dryness and mellowness can be explained by the fact that the presence of liquid can occur few days after the start of T-Thesys therapy. This counteracts the potential effects of the treatment. In addition, it should be taken into account that the response in knee mobilization after surgery is different among people (Minafra et al., 2007). The percentage of swelling had a peculiar trend, resulted at the end of the treatment above the recorded pre-test value. As concern the parameters articularity in angle degree showed a moderate improvement, though not statistically significant. Moreover, a simultaneous and progressive reduction in pain was achieved at the 7 th application.

Although no statistically significant, differences we found tend to a better clinical response compared to surgical treatment alone (Oliva et al., 2013).

Furthermore, we observed that the cost of the T-Thesys therapy use is economically justified and within the universally accepted limits considering the hospitalization days reduction and the savings on antiinflammatory drugs. These considerations play a key role in the use of the National Health System resources, in the hospital management and, also, in the consequent improvement of the quality of life in patients.

\section{CONCLUSIONS}

In conclusion, our results suggest that, for this kind of knee surgery, the therapeutic treatment with T-Thesys after ACL reconstruction does not have any additional benefits compared to the surgical treatment alone. In our opinion, the insufficient efficacy of this therapeutic device could be due to several biological variables subsequent to the surgery such as: the joint condition of dry, which appear to decrease after the treatment with T-Thesys and the simultaneous increase in swelling and mellow, that occur from the 3rd to the $7 \mathrm{~h}$ application, seems to demonstrate the ineffectiveness of the therapy.

The apparent deterioration can be interpreted as a subjective response to the knee mobilization after surgery. However, though the results were not statistically significant, it is necessary to report a better clinical response compared to the surgical intervention only. Previous studies demonstrated the efficacy of this treatment in musculotendinous and skeletal injuries (epicondylitis, muscle bruise and distraction, tenosynovitis, fibromyositis, cervicobrachialgia, post-traumatic edema, amputation stumps, bursitis and capsular-ligament distraction) (Francavilla et al., 2016; Ridola et al., 2007).

Based on our clinical experience, we found the use of T-Thesys therapy useful in the treatment of the traumatological sports diseases.

Finally, it is important to highlight the easy use of this device, the non-invasive method of application, the high tolerability threshold (in no case was it necessary to interrupt the therapeutic treatment), and the absence of side effects both locally and systemically.

Regarding the economic management of patients suffering of traumatic sports diseases or of degenerative soft tissue diseases, the treatment with T-Thesys seems to reduce cost management in terms of diminution 
of anti-inflammatory and pain-relieving drugs use and hospitalization days spent. Features that increase the quality of life of patients and, moreover, let to a rapid return to sport.

\section{REFERENCES}

Aicale, R., Tarantino, D., \& Maffulli, N. (2018). Overuse injuries in sport: a comprehensive overview. J Orthop Surg Res, 13(1), 309. https://doi.org/10.1186/s13018-018-1017-5

Ardern, C. L., Bizzini, M., \& Bahr, R. (2016). It is time for consensus on return to play after injury: five key questions. Br J Sports Med, 50(9), 506-508. https://doi.org/10.1136/bjsports-2015-095475

Arnason, A., Sigurdsson, S. B., Gudmundsson, A., Holme, I., Engebretsen, L., \& Bahr, R. (2004). Risk factors for injuries in football. Am J Sports Med, 32(1 Suppl), 5S-16S. https://doi.org/10.1177/0363546503258912

Badtieva, V. A., Pavlov, V. I., Khokhlova, M. N., \& Pachina, A. V. (2018). [The application of bioresonance therapy for the correction of the overtrained athlete syndrome]. Vopr Kurortol Fizioter Lech Fiz Kult, 95(6), 51-57. https://doi.org/10.17116/kurort20189506151

Bell, D. R., Post, E. G., Biese, K., Bay, C., \& Valovich McLeod, T. (2018). Sport Specialization and Risk of Overuse Injuries: A Systematic Review With Meta-analysis. Pediatrics, 142(3). https://doi.org/10.1542/peds.2018-0657

Byrne, J. D., Yeh, J. J., \& DeSimone, J. M. (2018). Use of iontophoresis for the treatment of cancer. J Control Release, 284, 144-151. https://doi.org/10.1016/j.jconrel.2018.06.020

Coscia, F., Gigliotti, P. V., Piratinskij, A., Pietrangelo, T., Verratti, V., Foued, S., . . Fano-Illic, G. (2019). Effects of a vibrational proprioceptive stimulation on recovery phase after maximal incremental cycle test. Eur J Transl Myol, 29(3), 8373. https://doi.org/10.4081/ejtm.2019.8373

Dobrindt, O., Hoffmeyer, B., Ruf, J., Seidensticker, M., Steffen, I. G., Fischbach, F., . . Amthauer, H. (2012). Estimation of return-to-sports-time for athletes with stress fracture - an approach combining risk level of fracture site with severity based on imaging. BMC Musculoskelet Disord, 13, 139. https://doi.org/10.1186/1471-2474-13-139

Foti, C., Annino, G., D'Ottavio, S., Sensi, F., Tsarpela, O., Masala, S., .. Bosco, C. (2009). Preliminary study on the effects of high magnitude, low frequency of whole body vibration in physical activity of osteoporotic women. Med Sport, 62(1), 97-106.

Francavilla, V. C., Bongiovanni, T., Genovesi, F., Minafra, P., \& Francavilla, G. (2015). La Bia segmentale: metodica utile per il follow-up di una lesione muscolare? Un caso clinico. Med Sport, 68(2), 323-334.

Francavilla, V. C., Bongiovanni, T., Todaro, L., Genovesi, F., \& Francavilla, G. (2016). Risk factors, screening tests and prevention strategies of muscle injuries in élite soccer players: a critical review of the literature. Med Sport, 69(1), 134-150.

Franklyn-Miller, A., Roberts, A., Hulse, D., \& Foster, J. (2014). Biomechanical overload syndrome: defining a new diagnosis. Br J Sports Med, 48(6), 415-416. https://doi.org/10.1136/bjsports-2012$\underline{091241}$

Gharaibeh, B., Chun-Lansinger, Y., Hagen, T., Ingham, S. J., Wright, V., Fu, F., \& Huard, J. (2012). Biological approaches to improve skeletal muscle healing after injury and disease. Birth Defects Res C Embryo Today, 96(1), 82-94. https://doi.org/10.1002/bdrc.21005

lovane, A., Di Gesu, M., Mantia, F., Thomas, E., \& Messina, G. (2020). Ultrasound-guided percutaneous treatment of a calcific acromioclavicular joint: A case report. Medicine (Baltimore), 99(1), e18645. https://doi.org/10.1097/md.0000000000018645

Kasha, P. C., \& Banga, A. K. (2008). A review of patent literature for iontophoretic delivery and devices. Recent Pat Drug Deliv Formul, 2(1), 41-50. https://doi.org/10.2174/187221108783331438 
Kvist, J. (2004). Rehabilitation following anterior cruciate ligament injury: current recommendations for sports participation. Sports Med, 34(4), 269-280. https://doi.org/10.2165/00007256-20043404000006

Minafra, P., Francavilla, G., Pancucci, G., Parisi, A., \& Francavilla, V. C. (2007). T-Thesis terapia nei traumi muscolari da sport: follow-up ecografico. Med Sport, 60(1), 45-46.

Monticone, M., Baiardi, P., Nava, T., Rocca, B., \& Foti, C. (2011). The Italian version of the Sickness Impact Profile-Roland Scale for chronic pain: cross-cultural adaptation, reliability, validity and sensitivity to change. Disabil Rehabil, 33(15-16), 1299-1305. https://doi.org/10.3109/09638288.2010.527030

Monticone, M., Ferrante, S., Salvaderi, S., Rocca, B., Totti, V., Foti, C., \& Roi, G. S. (2012). Development of the Italian version of the knee injury and osteoarthritis outcome score for patients with knee injuries: cross-cultural adaptation, dimensionality, reliability, and validity. Osteoarthritis Cartilage, 20(4), 330-335. https://doi.org/10.1016/i.joca.2012.01.001

Oliva, F., Via, A. G., Kiritsi, O., Foti, C., \& Maffulli, N. (2013). Surgical repair of muscle laceration: biomechanical properties at 6 years follow-up. Muscles Ligaments Tendons J, 3(4), 313-317. https://doi.org/10.32098/mlti.04.2013.12

Pariser, D. M., \& Ballard, A. (2014). Iontophoresis for palmar and plantar hyperhidrosis. Dermatol Clin, 32(4), 491-494. https://doi.org/10.1016/i.det.2014.06.009

Ridola, C. G., Cappello, F., Marciano, V., Francavilla, C., Montalbano, A., Farina-Lipari, E., \& Palma, A. (2007). The synovial joints of the human foot. Ital J Anat Embryol, 112(2), 61-80.

Slavotinek, J. P. (2010). Muscle injury: the role of imaging in prognostic assignment and monitoring of muscle repair. Semin Musculoskelet Radiol, 14(2), 194-200. https://doi.org/10.1055/s-0030-1253160

Toonstra, J., \& Mattacola, C. G. (2013). Test-retest reliability and validity of isometric knee-flexion and extension measurement using 3 methods of assessing muscle strength. J Sport Rehabil, 22(1). https://doi.org/10.1123/jsr.2013.tr7

Vahed, L. K., Arianpur, A., Gharedaghi, M., \& Rezaei, H. (2018). Ultrasound as a diagnostic tool in the investigation of patients with carpal tunnel syndrome. Eur J Transl Myol, 28(2), 193-197. https://doi.org/10.4081/ejtm.2018.7406

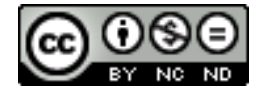

This work is licensed under a Attribution-NonCommercial-NoDerivatives 4.0 International (CC BY-NC-ND 4.0). 